\title{
Witness Testimonies of the Holocaust and the Meaning of Memory
}

\section{by Yehudi Lindeman}

Almost fifty years after the events, the conspiracy of silence on the part of bystanders and victims of the Holocaust, is at last beginning to be lifted and exposed. In its place come re-examination, new historical documentation and, increasingly, eye-witness accounts. Though the former victims are motivated by their last-minute chance to set the historical record straight against what is viewed as the Nazi war against memory, their new eagerness to testify is tempered by an ambivalence caused by their pain and loss. Meanwhile, the policies of indifference, silent abandonment and quiet collaboration on the part of nearly all the occupied European countries as well as the North American powers are now being exposed and re-evaluated. At the same time, the voice of the child survivors, those who were children during WWII, is increasingly being heard. As they break through their previous silence, some of their testimony seems to mark a new perspective. At best, it offers both to society and to them, the last and youngest eye-witnesses of the Shoah, a renewed opportunity for integration, healing and closure.

Près de 50 ans plus tard, la conspiration du silence des témoins et victimes de l'Holocauste commence à être déjouée et à céder la place à un réexamen, à de nouveaux documents historiques et à des témoignages de plus en plus nombreux. Même si les victimes de la Shoah sont motivées par la dernière chance qui leur est offerte de dissiper toute confusion historique possible sur ce qui constitue à leurs yeux une véritable guerre nazie contre la mémoire, ce désir renouvelé de témoigner est tempéré par l'ambivalence que suscitent le drame et le chagrin qu'elles ont vécus. Parallèlement, les politiques d'indifférence, d'abandon silencieux et de collaboration de la part de presque tous les pays européens occupés ainsi que des puissances nord-américaines sont exposées au grand jour et réévaluées. De même, les voix des survivants qui n'étaient que des enfants pendant la Deuxième Guerre mondiale se font de plus en plus entendre. Rompant leurs long silence, leurs témoignages offrent de nouvelles perspectives. Au mieux, ils donnent à la société et aux dernières et plus jeunes victimes de la Shoah l'occasion renouvelée de s'intégrer, de guérir et de clore un chapitre de l'histoire.

\section{"One man will always be left alive to tell the story." -Terrence Des Pres, The Survivor}

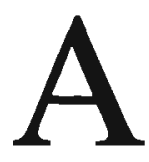

n earlier article, "Breaking the Silence and Bridging the Gap: Documenting Personal Memories of the Holocaust (Fontanus V, 1992), briefly explored the mandate of "Living Testimonies," McGill University's Video Archive for Holocaust Documentation (founded 1989). As the work on this McGill research project continues, the perspective of diminishing time is the most pressing factor on everybody's mind. All those involved in the project have been singularly motivated by the knowledge that today's interviewees are part of a rapidly declining segment of the population. ${ }^{1}$

\section{INTRODUCTION: A SIGNAL IN TIME}

With World War II increasingly recognized as the central event of the century, one may well argue that the Holocaust is its most pivotal manifestation. It happened and thus it can happen again, Primo Levi once remarked. For the world anno 1994, with its multiple references to "genocide" and "ethnic cleansing," the Shoah (I prefer the specific Hebrew term over the more generic "Holocaust") may plausibly serve as a reference point, or a signal in time of what at our worst we are capable of. It is a kind of "absolute point zero," says scientist and interviewee Jakub Gutenbaum, a Polish survivor of Auschwitz and Maidanek. And it deserves to be remembered because we are, all of us, "at some distance to that pole. Each event has a relation to it. It is very important to have such a reference point."

Others disagree and deplore the undue emphasis on remembering the Holocaust as alien to the spirit of Judaism and alienating to young Jews everywhere. "To 


\section{Witness Testimonies of the Holocaust and the Meaning of Memory}

have the major Jewish museums consecrated to the destruction of Jewry seems to me exceedingly perverse," says Ruth Wisse, formerly of McGill and now a Professor of Jewish literature at Harvard. ${ }^{2}$

It is likely that this very rational position is going to be around for some time to come. It implies that we should not be overburdened by memory. After all, remembering and commemorating are usually annual activities. Based on ritual events (national defeat or victory, or individual birth), they are celebrated at certain regular intervals only. It could also be argued that each generation has the right to set out with a fresh perspective, i.e., to start unencumbered by the cumulative burden of history. All young people should be able to start life with a clean slate and then create their own, new terms of reference.

The question of memory is a difficult and sensitive one. For so long, the ruling mentality has been to remain blind and deaf to the past. Until today, many countries and nations (the Germans among them) have suffered from individual and collective amnesia. Yet with many people finally willing to tell their stories one may wonder if this is not a particularly ill-chosen time in history to close the lid on memory.

This article is predicated on the belief that it is important to break the silence. It confronts the issue of silence in relation to the project's underlying function of preserving the message of the survivors and witnesses for a generation to whom the Shoab will bave passed into history. ${ }^{3}$ As such, it analyzes and enlarges upon the discussion in the earlier Fontanus article while creating a context for the work associated with the Archive to date.

"The entire history of the 'millenial Reich' can be reread as a war against memory. " -Primo Levi, The Drowned and the Saved.

\section{SILENCE AND HISTORY}

When G.L. Durlacher, from the perspective of middle age, looks back at his experiences in Auschwitz as a sixteen year old boy, standing for hours at a time at roll-call, to be counted over and over again during the daily counting ritual known as Zählappell, "grey with exhaustion, the head dizzy, the stomach hollow with emptiness," the most striking aspect of his situation, one on which he frequently comments, is his sense of absolute isolation and abandonment. For as nobody heard them or seemed to acknowledge them that day in early August 1944 (not even the American bombers that on that particular day seemed close to strafing the camp's crematoria, but had other business to attend to), the young slave labourers of the Männerlager (camp for men) Auschwitz-Birkenau B II seemed to be forgotten by the world. ${ }^{4}$ Primo Levi, working as a slave labourer in nearby Buno-Monowitz at the same time as Durlacher, comments, in a memoir that carefully balances recalled experience with reflexion, that this is exactly what the Nazis had in mind: not only to command the right or presumed right "of a superior people to subjugate or eliminate an inferior people, ${ }^{15}$ but to isolate the people first from the rest of the world, and eventually even from the collective history in which we all share. To be abandoned by history, to have, in a truly Orwellian sense, no longer recourse to the memory of mankind, is exactly what the Third Reich bad in store for its most chosen victims. As the SS guards put it, in the memory of one survivor, "We will be the ones to dictate the history of the Lagers. "6

Several interviewees of Living Testimonies were bluntly forced by the SS to participate in the Nazi ritual of altering history by exhuming from mass graves the bodies of earlier massacres. What Primo Levi terms the forced suppression of the "material evidence of the mass extermination"7 was actively launched in the fall of 1944, when German defeat and with it the future exposure of German crimes against humanity had become a plausible reality. Thus Rena from Krakow was forced to help cover the Nazi's tracks by digging up the bodies of earlier massacres in camp Plaszów with a spade and pile them onto a pyre for burning. Her testimony and that of others are an indication to Holocaust deniers then and now that history cannot be easily suppressed altogether.

To many of the victims, it must have seemed that their principal goal in life would be to bear testimony, in the unlikely event that any one of them would survive long enough to tell the story. The accents vary, but the rnessage is the same. When his book about Auschwitz was accepted by a German publisher, Primo 


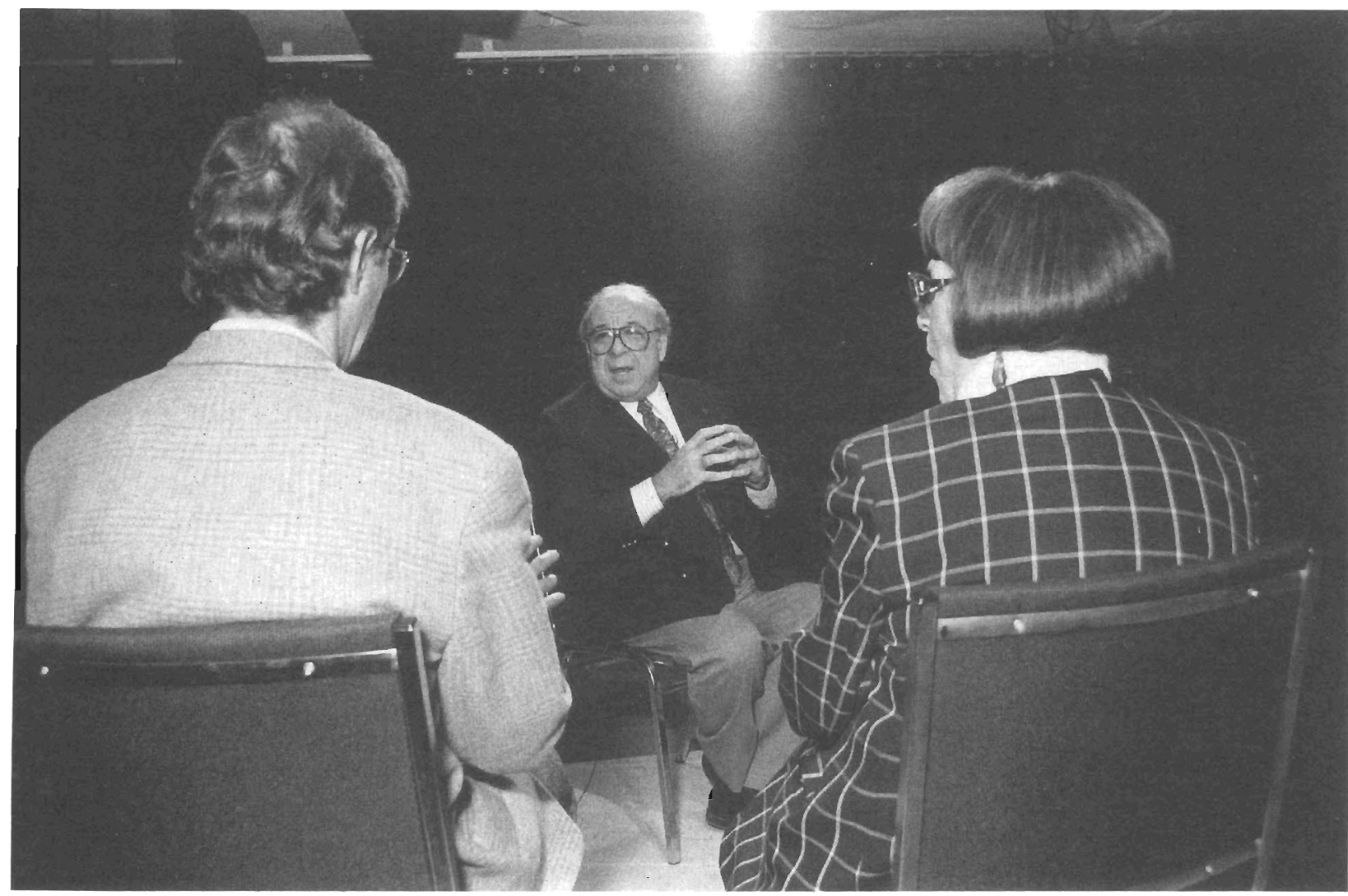

Most of the interviews for Living Testimonies are recorded in the ICC studio of McGili University. The interviews are conducted by one or two voiunteer interviewers

Levi wanted the Germans to know all the things that had occupied him for so long, in order to "tell them, indeed, shout them from the rooftops." 8 Alexander Donat's mission was to "hurl [the Ghetto's history] into the face of the world." 9 An exhumation even more horrible than that in Plaszów, on account of its much larger scale, took place in Treblinka. It was precisely the knowledge that soon "Treblinka" would cease to exist in history that led, against overwheiming odds, to the well documented, implausible rebellion of August 2, 1943. As Terrence Des Pres put it, "The aim of the revolt was to ensure the memory of that place, and we know the story of Treblinka because forty [people] survived." 10

Writing long and carefully detailed ietters to her Amsterdam friends from transit camp Westerbork, from which inmates were deported directly, and with icy bureaucratic precision, to Auschwitz once or twice a week, a young Dutch woman watches the departires and testifies to the world about what she sees. Her name is Etty Hillesum. On this particular pre-dawn and early dawn morning (it is August 21, 1943) exactly 1020 Jews are counted again and again as they are crammed into box cars bound for some unknown destination in Poland. The witness report contains graphic scenes as young and old, babies and sick people, pregnant women and old men are crowded into the cars, until the final blow of the whistle announces the start of the journey to the east. Even as she recounts the infernal sights of the departing rituals in her letter, the narrator explains, almost humbly: "One always has the feeling here of being the ears and eyes of a piece of Jewish history... We must keep one another in touch with everything that happens in the various outposts of the world..."11 Less than a month later, it will be Etty Hillesum's turn to be similarly deported. She will not survive, but her letters do. That same autumn of 1943, while she herself is still alive in Auschwitz, two of these long letters are 
published illegally in occupied Holland and quickly distributed by couriers working for the Dutch underground. They are read by thousands of people.

Many of the interviewed survivors have confirmed their need to bear witness. We have this obligation to tell the story, says Ted: "As we have no graves for those who perished, our memories are (in a phrase borrowed from an inscription in the Venice ghetto) their only graves." Ted claims that what saved his life was having what he self-consciously calls two "good jobs", first by working in the kitchen and later by being an "undertaker," i.e., carrying bodies and transporting them to a mass grave. Being an undertaker saved my life, he wryly comments.

Quite often the ability to tell the story is based on very mixed feelings. But the desire to tell the world what happened is often accompanied by an equally profound or even deeper need to redress some balance inside. "They tried to kill me and turn me into an animal," says Abraham, and then, not without satisfaction, "They didn't succeed. I survived... and Hitler is dead. I danced on his grave."

"The perpetrators should not sleep quietly at night," says Bonno who is, like Abraham, a survivor of the Lodz ghetto and Auschwitz. And in a tone which resembles that of Simon Wiesenthal or Serge Klarsfeld, but is clearly all bis own, he adds, "I don't want revenge. I want justice."

"We are the last witnesses," says Renata with a mixture of sadness and pride, "after us there will be nobody to tell the story." Yet she insists that in spite of the loss and the pain that never go away, she is indeed a survivor in the sense that she has remained human. "My success is that I retained my humanity, that I am a human being," she says. A survivor of the Warsaw ghetto, she was first interviewed at McGill in 1989 and is now active as an organizer for Living Testimonies and one of its principal interviewers. But it took Renata more than four decades before she was able to tell her story. Encouraged by her daughter, she finally made the move. The result was a lot of pain alongside a strong personal sense of liberation. Meanwhile her two children marvelled at some of the incidents that were now uncovered to them for the first time. In another example, Rubin's three married sons first learned about the details of their father's experiences in Auschwitz, Buna-Monowitz and Buchenwald, among other places, while watching the video-taped interview in their respective homes. (It is the project's policy that each survivor receives a VHS copy shortly after the studio session.)

This kind of ambivalence, the strongly felt need to testify that is balanced against the accompanying sadness or terror, the pride at surviving versus the loss of so many and so much, is found in many eye witness accounts. A good example is that of Phil whose testimony for the Yale Archive is appended, as a kind of epilogue, to Lawrence Langer's Holocaust Testimony:

We have not only survived, but we have revived ourselves. In a very real way, we have won. We were victorious. But in a very real way, we have lost. We'll never recover what was lost. ${ }^{12}$

In attempting some kind of summary, one may turn to Elie Wiesel's story about the Jewish historian Simon Dubnow for bits of necessary insight. As Dubnow is being deported from his home in Riga, along with his fellow-Jews, he is said to have urged them to remember everything: "Open your eyes and ears, remember every detail, every name, every sigh! The colour of the clouds, the hissing of the wind in the trees, the executioner's every gesture: the one who survives must forget nothing!"13 The outcry is very powerful and persuasive. Yet at the same time, the sense of abandonment and loss it contains is so great that the very terror and despair (what Des Pres has aptly termed the "screan") that should give rise to the witness report and propel it out into the world as "living testimony," may equally stifle its expression and reduce it to unutterable silence.

\section{SILENCE AND THE OUTSIDE WORLD}

Re-reading or viewing the reactions of the world to the plight of the Jewish people before, during and immediately after the Shoah, one runs the chance of being overcome by a different kind of despair at the ominous prevalence of silence almost everywhere. This 
may have been the reaction on the part of those who watched the recent PBS television special America and the Holocaust: Deceit and Indifference. This one and a half hour documentary shows in chilling detail what powerful political forces were at work, during WWII, first of all to keep Jews out of America; and second, to keep America out of any meaningful involvement with the European Jews, by maintaining a detached silence about the on-going massacres. The specific goal of the TV documentary was to reveal something of the strict policy of silence, on the part of the U.S. government, that kept the allied and American military from becoming implicated in any rescue operations. Even as late as 1944 their interventions might have saved hundreds of thousands of Hungarian Jews from being gassed at Auschwitz. In this sense, the abandonment intuitively felt by Durlacher (remembered in his memoir) while he himself and his fellow-prisoners stood at attention to be counted during their daily and endlessly repeated Zählappell, was entirely justified. Whereas only kilometers away from his Männerlager, literally endless lines of Hungarian Jews coiled towards the gas chambers every long summer day, a different kind of ritual, that of the ever-returning allied bombers, took place each day less than a few kilometers above their heads. But the targets of these large scale and daring British and American bombing missions were the industrial complexes of nearby I.G. Farben and other German factories, and never the gas chambers and crematoria; the latter were not considered priority military targets.

Such are the conclusions of well documented books by, among others, Arthur Morse in While Six Million Died and David Wyman in The Abandonment of the Jews. Wyman's own moving testimony in the above mentioned PBS TV documentary completes the impression that what has since become known as a "conspiracy of silence" pervaded the Western world, from the media to the top echelons of government.

For those wanting documentation about Canada's attitude towards the Jews during WW $\Pi$, there is now an abundance of documentation showing how that country quietly barred its doors against the entry of all refugees of Jewish origin. Canada's attitude towards letting in any Jews at all is well summed up by the title of the book None is Too Many, by historians Irving Abella and Harold Troper.
In Europe, especially in France and Holland, toughminded young historians are moving at great speed to uncover evidence that had been quietly overlooked for almost fifty years: the massive and crucial support, varying from tacit assistance to zealous collaboration, on the part of the local civilian bureaucracies and police authorities. As a result, many tens of thousands of Jewish fellow-citizens were deported to their ultimate murder sites in Eastern Europe. ${ }^{14}$

In fairness to the historical record, mention should at least be made of one people and government that acted speedily and successfully to save what they considered to be their fellow-citizens. The collective effort by the Danish people to rescue the Jews shows what might have been accomplished if other nations and governments had chosen the path of active solidarity instead of hesitant or devoted abandonment. As a result of the concerted Danish initiative of October 1943, almost all the Jews of Denmark were directly shipped to Sweden and arrived in safety. Of those who were deported to the Theresienstadt ghetto/concentration camp (481 in all), many survived. And while it is true that a considerable number of the Danish Jews perished in Theresienstadt of hunger and disease, this was not because of Danish silence or indifference. On the contrary, the documentation seems to suggest that the insistent Danish protests, combined with their attempts at support and communication, kept the inmates from an even worse fate. While there were large and frequent transports from Theresienstadt to Auschwitz and other death camps, not a single one of the Danish deportees was sent on to be gassed in an extermination camp.

The recent conviction in France of former Nazi collaborator Paul Touvier to a life sentence for crimes against humanity indicates that, in France at least, the silence of the past is in the process of being probed and reevaluated. After being pardoned by then President Pompidou, in 1971, Touvier has finally found his nemesis, which seems to indicate a new attitude on the part of the French. And this comes in spite of what is widely regarded as unusual leniency towards the former Vichy régime's collaborators on the part of current President Mitterand. 


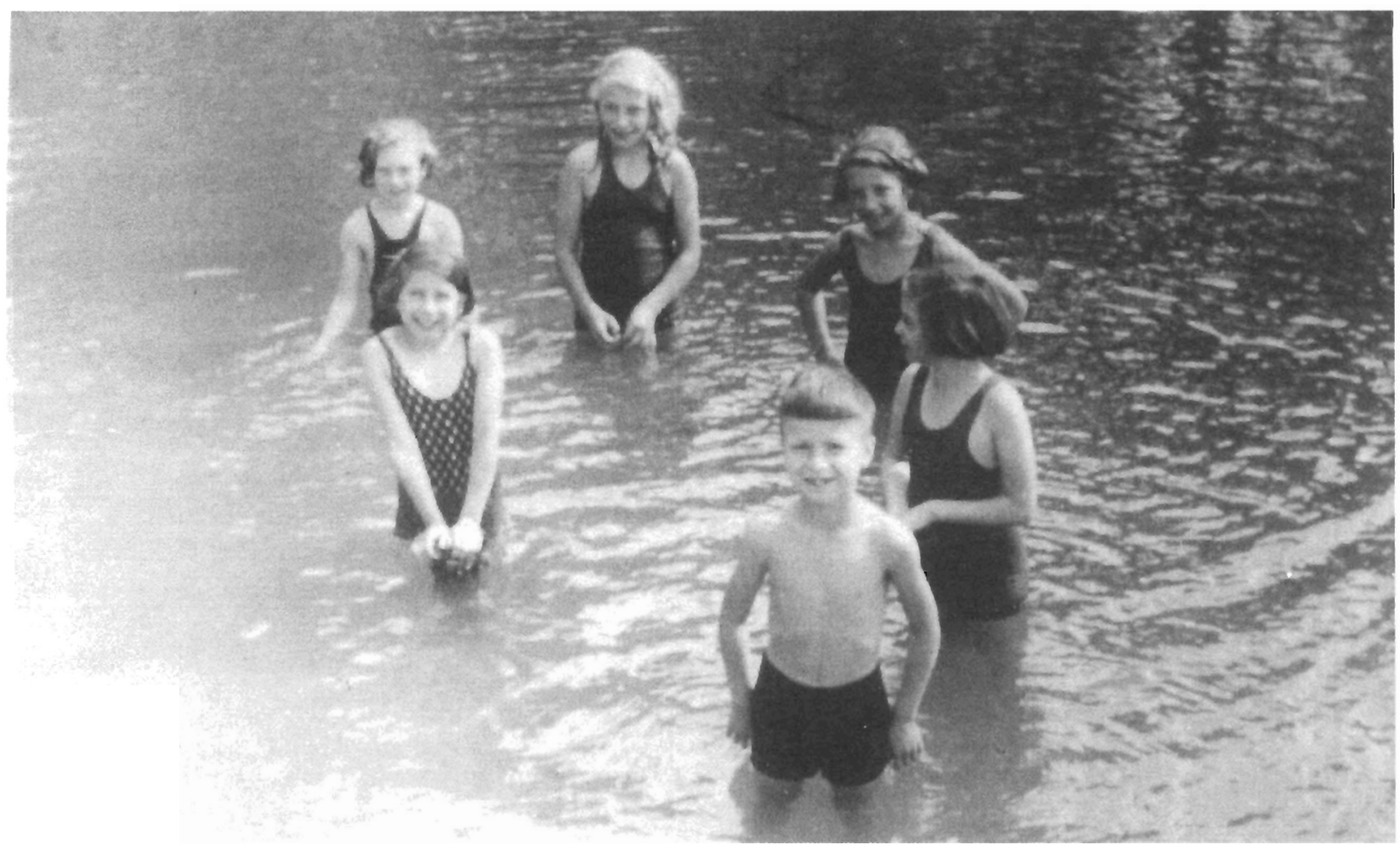

This picture of seeming pastoral bliss was taken by one of the children's benefactors, Philip Baron Van Pallandt, in the summer of 1943. Unlike other less fortunate youngsters hidden on the Baron's forested estate in an eastern province of the Netherlands, all of these Jewish children survived the war.

"For many years the members of my generation were concerned with the concealment and repression...the suppression of memory." --Aharon Appelfeld ${ }^{15}$

\section{THE SILENCE OF THE CHILDREN}

One feature of survivor memory that has received a lot of recent attention is what happened to the memory of those who were children during the Nazi persecution. This is also an aspect that increasingly occupies the interviewers for McGill University's Living Testimonies project. Naturally, with the passage of time, more and more of the interviewees are those who were six, ten or fourteen years old at the end of the war, or even mere toddlers whose memories consist at best of some vivid scenes, or clearly remembered sensations or visual fragments. Some were so young that they have no memory at all. Those who attended one of the recent conferences of child survivors and hidden children, may have seen seen desperate notes scrawled on strategically placed bulletin boards. Some of the youngest child survivors are still searching, after fifty years, for clues regarding their identity, including their family name and the name given them at birth. "Who am I?" read one of those queries, and after describing the place and time and some further identifying information, "Who can tell me my name and who my parents were?"

As for the older children, even while admitting that "memory is a problem" (as one scholar puts it), most have lived practically all their lives choked with memories that have been as keen and ever-present as they have been consistently repressed. "Most hidden children were encouraged to forget about their war experiences, " says the writer of an article in Newsweek, published prior to the large gathering (more than 1600 participants) of "Hidden Children" in New York in May 1991. ${ }^{16}$ If there was ever a concerted attempt to "crash the holes of oblivion, " a term attributed by Primo Levi to Hannah Arendt, it is in the cases of many of these "children."

The need to tell the story of what happened is probably as old as the time of mankind's first 
incursions into speech. And there is virtual unanimity about the benefits of speaking out and sharing one's stories with the world. As Eva Hoffman puts it in the New York Times Book Review, it is now "accepted wisdom that for victims of trauma the way to catharsis is through telling their story. "17 Or as rescuer Hetty Voûte and Dutch child survivor Nico agree, "You only get better once you start talking about it."

Yet almost to a person, the child survivors have remained mute about their experiences during the war, at least until recently. Among the various aspects that mark the experience of the survivor child (who, in the majority of cases, is one whose life during the war was saved in hiding, or by "passing" as a gentile on forged papers) are the suddenness of the separation and the smooth, chameleon-like adaptation of the children to their new, various situations. I Never Said Goodbye is the apt title of a French woman's account of the sudden parting, for ever, from papa and maman. It could serve as an emblem for the rupture that the war caused to those who were sixteen years old or younger at the time of liberation in 1945. Again and again, those watching our video testimonies, must encounter that one moment that constitutes the last time when the survivor would see his or her parents. Sam was present in the room when two French gendarmes led his mother away out of the house. He would never see her again. Arrested in June 1942, she was deported to the transit camp of Drancy and from there to Auschwitz. Daisy, who was born in Nitra in Czechoslovakia, remembers standing in the office of the lawyer who helped make the necessary arrangements for hiding her. Her parents were standing next to her. Though she was only five years old, she recalls her mother telling her that her new name would be Anicka, and that she should never tell anybody her real name or who she was. This was the last time Daisy would see her parents who were killed in Auschwitz.

Some of the most wrenching moments on any of the footage of Living Testimonies is when a child, with the help of a parent or older sibling, is forced out of a hole or narrow opening in the box car traveling to Auschwitz or Treblinka. That is how Mila, a native of Poland, jumped or fell to safety. Though she was lucky enough to survive the fall along with her sister and female cousin, a fourth child, her friend Olek, was killed in the attempted escape. Her parents stayed on the train and were killed immediately upon arrival in Auschwitz.
The abrupt and sudden change that is common to all these accounts, was probably even more keenly experienced by children than by adults. At the age of nine, Leah had only just enough time to read the results of her previous year on the board posted outside the school in her village in rural Romania. Pleased about learning that she had done well and was promoted to fourth grade, she was marched off, literally the next day, on a journey which, within months, would claim the lives of her parents and siblings, and turn her into the single orphan-survivor of her large family.

Though little has been written about it, the powers of adaptation of the child are generally acknowledged and praised. Hetty Voûte who was responsible for hiding and saving the lives of more than one hundred Jewish children in Holland, has expressed surprise at how sweet and obedient the children were and how good at keeping silent. Bloeme Evers-Emden, who has published extensively about hidden children in the Netherlands, comments on the unusual extent to which the children were "easy, nice and adorable. ${ }^{n 18}$ Sarah Moskovitz and Robert Krell have remarked how children hidden in convents, orphanages and farms "learned to play it safe, be quiet, and not be noticed." 19 Robert Krell, himself a hidden child in war-time Holland, was among the first to draw attention to the child survivor's descriptions of their ability to adapt "in chameleon-like terms."20 Sarah Moskovitz also observed the children's "wide range of adaptation. "21 Seven years later, Krell explains the children's quietness and adaptability in terms of their unusual cognizance of their situation, even at a very young age: "children...could not be playful or boisterous. They were taught to be silent." 22

Silent they were, both during and long after the war. Tom (who lost both parents) mentions that for him the real war started after the war, a commonly acknowledged theme among child survivors who often speak of the challenge of "surviving survival." Although Tom carefully avoided all contacts with his war past as well as his Jewish past, and tried hard to assimilate, he acknowledged that there has never been one day in his life when he wasn't thinking about something connected with the war. ${ }^{23}$

As a child hidden in Holland in more than fifteen locations, I can testify to both the adaptability and the silence, especially the silence. I can't remember ever talking to my peers or friends about any of my war 
experiences. Even and especially in the company of those with a similar past, I avoided any references to it, and thus along with my fellow children-in-hiding, contributed to a "conspiracy of silence" all our own. One example: I recognized Sophia at once by her striking long, black hair, the moment I arrived at the school. It was only minutes after I had entered, for the first time, the yard of my new elementary school, in the South of Amsterdam. She recognized me at once, for we had spent months together in hiding, along with about ten other Jewish children, in three different locations in the wooded hillside terrain of Eastern Holland. Eventually Sophia, Liesje and myself would end up as near-neighbours, along the same rural route, in the northern province of Freisland. Together we also witnessed and shared the arrival of the victorious Canadian troops, in April 1945. That day marked the end of fear and persecution for Sophia, Liesje and me as white loaves of bread, dark chocolate bars and Player's cigarettes were dispensed by smiling Canadian soldiers from their overweight tanks which mightily tore into the narrow asphalted road. I had been only seven years old at the time. I was still seven that day when I arrived at my new school. As I remember it, we greeted each other with quiet astonishment. But though Sophia and I spent the next five years in the same classroom, and even later, as University students, joined the same student club, we never again referred to the joint past that tied and bonded us beyond our rational will. All I can think is that the taboo surrounding it must have been a very powerful one.

Evidently my experience - of utter silence - was typical of all of us. "To whom should we have talked?" asked Ed Van Thijn, the then burgomaster of Amsterdam (currently Holland's minister of Interior Affairs) as he addressed the opening session of the Conference of Hidden Children gathered in Amsterdam, in August 1992. To the surprise of just about everybody, he revealed himself as one of us. "To whom?" To the physicians, the specialist? "I was a problem case," he explains. "I was even seen by a child psychiatrist. I got the wildest kinds of treatments, I even received electro-shock therapy. The war was never even mentioned. Not once did any of all those clever types ever ask me to tell my story." And he continues: "To whom else could we talk? Our peers? The kids in our class? Our friends?" They prove to be rhetorical questions. Not a single word is whispered to any of those with similar experiences. He concludes his conference address by recalling that when he once or twice, at an unguarded moment, said something or started to tell a story, an adult would promptly interrupt him by saying "What are you talking about? Remember, you were just a child..."

Since the first international conference of Child Survivors in Lancaster, Pennsylvania, six years ago, much has changed. Canada hosted a gathering of child survivors/hidden children from four different continents. At this large international conference, held in Montreal from October 7-10, 1994, the theme was the transition from "memory" to "legacy." The occasion was no doubt the excuse for the swapping and sharing of endless stories and personal anecdotes. What exactly will be done with these memories and these stories (including those that continue to be gathered by McGill's Living Testimonies) is not yet clear.

It may well take another generation or two before the full value of these communications can be determined - or maybe the interpretations and evaluations will continue to vary from one period to the next as scholars, educators and documentary film makers put their different individual spins on the testimonies. There is some indication that the use of those memories may lead to what Aharon Appelfeld has termed an enlargement of vision as the inhuman dimensions of the Holocaust are giving way to human responses and emphases. In that respect, Claude Lanzmann's epoch making film Shoah (1985) has evidently marked the conclusion of something old as well as the opening up and heralding of things quite new, even if its dimensions are still vague and tentative at best. Others contend that some of that is already happening anyway, with oral history providing, in the words of Robert Krell, the eye-witness accounts "so important to bistory, and for future education, "while at the same time allowing the child survivor to experience "personal well-being and a sense of closure. ${ }^{\text {"24 }}$ 
Witness Testimonies of the Holocaust and the Meaning of Memory

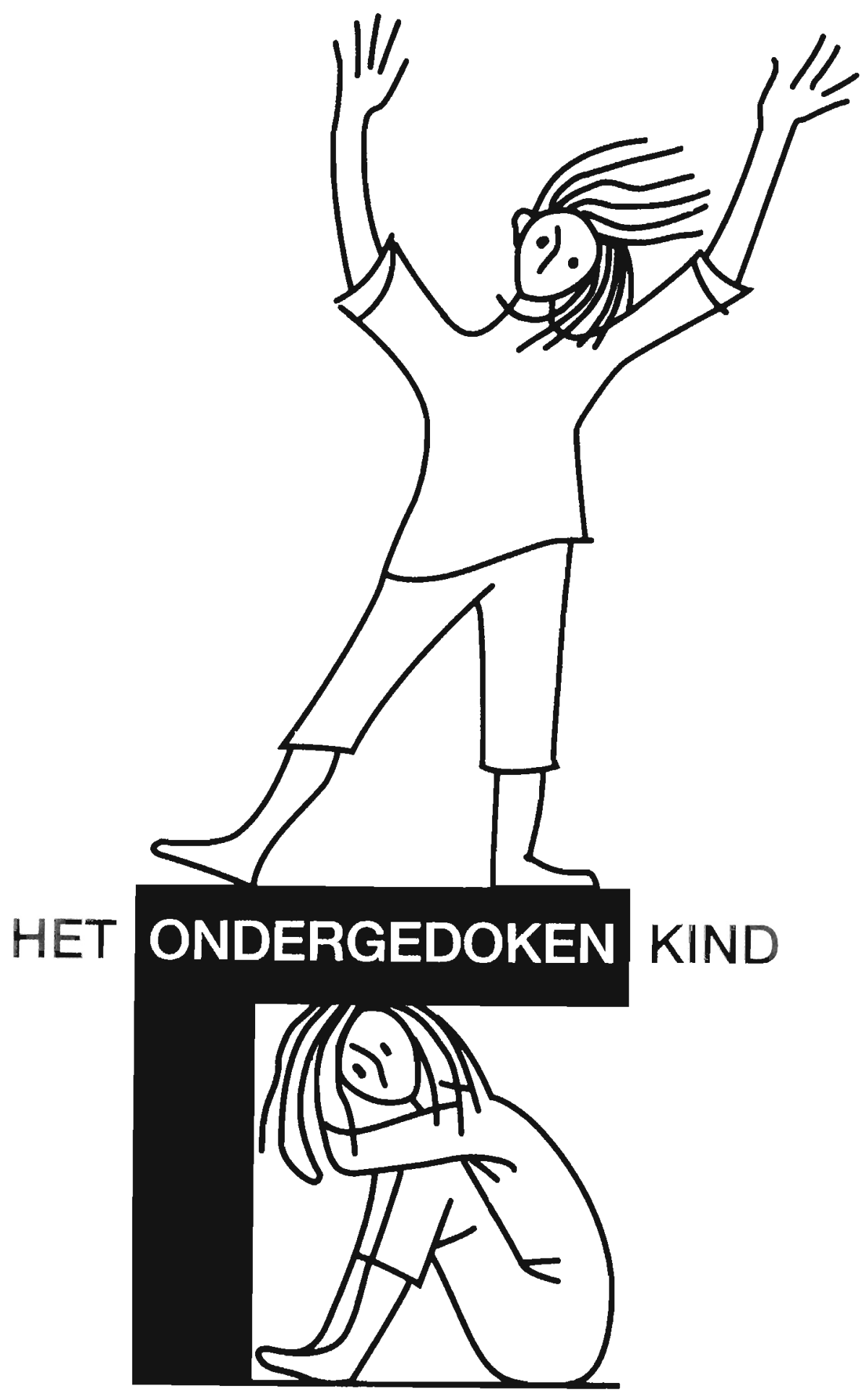

The iogo of the Convention of Hidden Children held in Amsterdam in August 1992. More than 500 Dutch (or former Dutch) children attended. 


\section{Notes}

1. The Archive collection of video taped recordings with survivors and witnesses of the Holocaust can be viewed locally at the audio-visual room of Living Testimonies at 515 Pine Avenue West. The master tapes are now in storage at the Department of Rare Books and Special Collections of the McGill Library of Humanities and Social Sciences. In addition parts of the collection of video tapes are now shared with similar projects at Yale University, the Simon Wiesenthal Center in Los Angeles, and Yad Vashem in Jerusalem.

2. Ruth Wisse's remarks to The Forward are quoted by Adam Dickter in his article "A Holocaust Obsession?" in Hadassah Magazine (April 1994), 19.

3. Cf. President Bill Clinton's observations, at the opening ceremony of the U.S. Holocaust Memorial Museum in April 1993, that "history" will soon be replacing living reality and shared experience and that it is exactly to preserve those that the Museum was consecrated so that, in the President's words, "we are now strengthened and shall forever be strengthened by memory."

4. Gerhard Durlacher, Stripes in the Sky (New York: Consortium Books, 1992). This work was originally published in Dutch in 1985 . For details on the deportations during the second half of 1944 and the allied bombings above and around Auschwitz, see also Michael Marrus, The Holocaust in History (Toronto: Lester and Orpen Dennys, 1987), 184-196.

5. Primo Levi, The Drowned and the Saved (New York: 1988), 115.

6. Primo Levi, 12.

\section{7. lbid.}

8. Primo Levi, 168.

9. Terrence Des Pres, The Survivor (Oxford: 1976; Oxford University Paperback, 1980), 31.

10. Ibid.

11. Etty Hillesum, Letters from Westerbork (New York: Pantheon, 1986), 124-139. The letter quoted here was one of two originally published illegally in Holland in late 1943. The same letter is also included in $A n$ Interrupted Life: The Diaries of Etty Hillesum 1941-43 (New York: Pantheon, 1984), the source of the actual quotation.

12. See Lawrence Langer, Holocaust Testimonies: The Ruins of Memory (New Haven: Yale University Press, 1991), 205.

13. Elie Wiesel, One Generation After (New York: Random House, 1970), 38-39.

14. Cf. the finished but as of this date unpublished recent study by Guus Meershoek, The Amsterdam Municipality, Its Police Force and the Persecution of the Jews.

15. Aharon Appelfeld as quoted in Eva Hoffman, "Let Memory Speak," New York Times Book Review (January 23, 1994), 5.

16. See Newsweek, April 15, 1991.

17. Eva Hoffman, 5.

18. Bloeme Evers-Emden, Onderduikouders en hun Joodse 'kinderen' over de onderduikperiode (Utrecht: ICODO, 1988), 84. Cf. also the same writer's Geleende kinderen (Kampen: Kok, 1994).

19. Sarah Moskovitz and Robert Krell, "Child Survivors of the Holocaust: Psychological Adaptations to Survival," Israeli Journal of Psychiatry Related Sciences, vol. 27, No. 2 (1990), 83.

20. Robert Krell, "Therapeutic Value of Documenting Child Survivors," Journal of the American Academy of Child Psychiatry, Vol. 24, No. 4 (1985), 399.

21. Sarah Moskovitz, "Longitudinal Follow-up of Child Survivors of the Holocaust," Journal of the American Academy of Child Psychiatry, Vol. 24, No, 4 (1985), 401.

22. Robert Krell, "Who is a Survivor," If Not Now (Toronto, Winter 1992), 3.

23. Nieuwe Rotterdamse Courant, 20 August 1992.

24. Robert Krell (1985), 399. 